This item was submitted to Loughborough's Research Repository by the author.

Items in Figshare are protected by copyright, with all rights reserved, unless otherwise indicated.

\title{
Built-in resilience through disaster risk reduction: operational issues
}

PLEASE CITE THE PUBLISHED VERSION

http://dx.doi.org/10.1080/09613218.2014.858203

PUBLISHER

Routledge (@) Taylor \& Francis)

VERSION

AM (Accepted Manuscript)

LICENCE

CC BY-NC-ND 4.0

REPOSITORY RECORD

Bosher, Lee S.. 2013. "Built-in Resilience Through Disaster Risk Reduction: Operational Issues". Loughborough University. https://hdl.handle.net/2134/14005. 
This item was submitted to Loughborough's Institutional Repository (https://dspace.lboro.ac.uk/) by the author and is made available under the following Creative Commons Licence conditions.

\section{creative
commons}

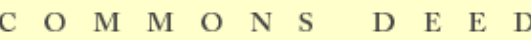

Attribution-NonCommercial-NoDerivs 2.5

You are free:

- to copy, distribute, display, and perform the work

Under the following conditions:

Attribution. You must attribute the work in the manner specified b the author or licensor.

Noncommercial. You may not use this work for commercial purposes.

No Derivative Works. You may not alter, transform, or build upon this work.

- For any reuse or distribution, you must make clear to others the license terms of this work.

- Any of these conditions can be waived if you get permission from the copyright holder.

Your fair use and other rights are in no way affected by the above.

This is a human-readable summary of the Leqal Code (the full license).

\section{Disclaimer 만}

For the full text of this licence, please go to: http://creativecommons.org/licenses/by-nc-nd/2.5/ 


\title{
Built-in resilience through disaster risk reduction: Operational issues
}

\author{
Lee Bosher \\ School of Civil and Building Engineering, Loughborough University, \\ Loughborough LE11 3TU, UK \\ Email: L.Bosher@Lboro.ac.uk
}

\begin{abstract}
It has been argued that the broad range of people responsible for the delivery, operation and maintenance of the built environment need to become more proactively involved in making the built environment resilient to a wide range of known and unforeseen hazards and threats. Accordingly, the (actual and potential) roles of a wide range of stakeholders associated with the integration of Disaster Risk Reduction into the (re-)development of the built environment are examined. A review of literature, government data and interviews with key stakeholders in England, highlights that despite regulatory intentions to increase local resilience through the use of public and private sector stakeholders, a number of structural and operational obstacles exist. A range of strategies can be employed to overcome these obstacles: revisions to building codes, tightening planning policy, improving professional training, clarifying roles and missions, enabling complementary bottom-up and top-down approaches, and the provision of good practice guidance about the broad range of structural and non-structural risk reduction measures. Many of the operational challenges are non-structural and require a coherent, overarching strategy: changing and aligning the social understandings and practices in civil society, government and building environment stakeholders.
\end{abstract}

Keywords: built environment, disaster mitigation, governance, professionals, risk reduction, resilience, proactive strategies, stakeholders 


\section{Introduction}

While hazards, such as earthquakes, cyclones and tsunamis are natural in origin; the way that disaster risk has become embedded in the contemporary urban landscape is largely anthropogenic. Decades of mass urbanisation accompanied by poor urban planning, non-existent or poorly regulated building codes and little or no proactive adaptation to the impacts of climate change has increased humanity's exposure to these hazards.

The last century has witnessed an expansion of urban populations across the world. This mass urbanisation has occurred in the context of neo-liberal policies in which the role of the state as an urban custodian has gradually been diluted (Johnson et al. 2013). For urban planning and construction, this has resulted in a reduction in regulatory control and a perspective that the role of the state is primarily to enable 'free' markets to work. The implication for the construction sector is to enable investments in construction through the provision of infrastructure, financial mechanisms and making land available for development. However, reduced (or ineffectively applied) regulatory controls have meant that disaster risks, and other environmental concerns, are often poorly considered in urban development decisions (Wamsler 2006; UNISDR 2011; Johnson et al. 2013).

The relative increase over the last two decades in the number of large-scale disasters, the amount of people being affected and the economic losses generated (UNISDR 2013a) indicates this situation needs to improve sooner rather than later. It has therefore been argued that the many professionals involved in the delivery and operation of the built environment need to become part of the proactive strategies associated with Disaster Risk Reduction (DRR) where structural and non-structural approaches to 'build-in resilience' could be achieved (Wamsler 2006; Benson and Twigg 2007; Bosher et al. 2007; Bosher and Dainty 2011). However, it is widely acknowledged that 'resilience' is a rather nebulous concept that has been adopted and adapted by numerous disciplines (Reghezza-Zitt et al. 2012; Alexander 2013; Vale 2013). Consequently it is not always clear what 'resilience' actually means or the extent to which the term is scientifically founded or can accurately be applied or measured.

In light of the paucity of specific definitions of 'built-in resilience', the concept has been influenced by Bosher's (2008) definition of a resilient built environment that:

'should be designed, located, built, operated and maintained in a way that maximises the ability of built assets, associated support systems (physical and institutional) and the people that reside or work within the built 
assets, to withstand, recover from, and mitigate for, the impacts of extreme natural hazards and humaninduced threats.'

(Bosher 2008, p. 13)

Therefore, 'built-in resilience' is not merely about the creation of physical assets in an appropriate way and in suitable locations, it is equally important to increase the capacity of the social, institutional and economic support mechanisms in order to keep the built environment operational and adaptable. Hence, built-in resilience is a quality of a built environment's capability (in physical, institutional, economic and social terms) to keep adapting to existing and emergent threats. This holistic, structural and non-structural, view of 'built-in resilience' has received increasing acknowledgment in academic research during recent years (see Williams and Jacobs 2011; Hynes and Purcell 2012; Jabareen 2012; Wamsler 2012). Nonetheless, there is insufficient understanding of how DRR can be used practically to attain built-in resilience or indeed whether the 'built-in resilience' concept provides a suitably useful lens to understand how a range of structural and non-structural DRR activities can be best integrated.

Drawing upon a review of literature, government data and interviews with key stakeholders, this paper considers what a resilient built environment should be and whether it is possible for resilience to be achieved for unforeseen as well as anticipated risks. When deliberating nebulous concepts such as resilience the discussions can get entrenched in semantic and ideological arguments. Therefore this paper will endeavour to provide examples of how 'built-in resilience' (through DRR related activities) is being operationalised at the local level in England. The types of practical DRR approaches that can be adopted are explained and the wide range of built environment professionals (public and private sector) that should be involved in increasing the resilience of the built environment are identified. With a particular focus upon 'new builds', some key obstacles to the attainment of 'built-in resilience' are discussed. Recommendations are provided for possible strategies to overcome these obstacles along with reflections on the relevance of the 'built-in resilience' concept in relation to DRR activities.

\section{Methodology}

Between January 2009 and December 2012, a broad range of professionals from England involved with construction (40\%), ${ }^{1}$ insurance (5\%), emergency/security management (30\%), local and national government (10\%), urban planning (5\%), and academic research (10\%) were interviewed with the aim of better understanding who should do what and when in relation to making the built environment more 'resilient'. In total the 40 interviews investigated how resilience is defined in practice, identified examples of good (and not so good) DRR practice as well as suggestions 
about how the resilience of the built environment could be increased. Over 40 hours of interview transcriptions were thematically coded using NVivo qualitative data analysis software.

The stakeholder matrixes that are presented in Appendices 1 and 2 were based upon previous research undertaken by Bosher et al. (2009) that was then further developed and updated during the aforementioned interviews. The stakeholder matrices were then validated using scenario based discussions that were conducted during two multistakeholder focus groups involving a total of eleven respondents; conducted in November 2011 (six respondents) and June 2012 (five respondents).

\section{What is resilience?}

Madni (2007) makes the observation that resilience is a semantically overloaded concept in the sense that it tends to mean different things to different disciplines. Six years later, it is fair to say that the semantics associated with 'resilience' are now even more overloaded and the differences have become even fuzzier at the interfaces of the different disciplines. The problems with defining 'resilience' are a by-product of the difficulties in operationalising the concept (for instance, by designing strategies to achieve resilience in diverse and often dynamic circumstances (Alexander 2013)). The current research reviewed publications that conceptualise resilience in a number of ways, such as resilient engineering, urban resilience, ecological resilience, economic and business resilience, industrial and organisational resilience, community resilience, psychological resilience and socio-ecological resilience. During this review (and as also noted by Alexander 2013) it was clear that the 'resilience' term was often used by one discipline without suitable reference to how other disciplines also conceptualise the term.

Notwithstanding some ancient etymological roots, ${ }^{2}$ the concept of resilience chiefly emerged in modern day research concerned with how ecological systems cope with stresses or disturbances caused by external factors (see Errington 1953; Blum 1968; Holling 1973), but has more recently been applied to human social systems (Manyena 2006), economic recovery (Rose 2004), engineering (Hollnagel et al. 2006; Madni and Jackson 2009; Hollnagel 2013) and urban planning and recovery after calamitous events (Vale and Campanella 2005). Coaffee (2008) argued that there are three key dimensions which differentiate resilience from traditional notions of disaster planning and recovery. Firstly, the emphasis is on hazard mitigation and preparedness rather than post-disaster management. Secondly, there has been a widening of the emergency planning agenda to embrace security challenges in addition to natural hazards and technological 'accidents', this is despite the fact that the latter categories have a far greater collective 
impact. The third dimension concerns the role of institutional resilience to protect key infrastructural systems. This has necessarily broadened out the range of professions and institutions whose input must now be garnered and integrated into the resilience effort (Bosher et al. 2007; Vale 2013). Such perspectives cross-cut the multidisciplinary and dynamic focus of this paper and the potential appropriateness of DRR measures in relation to their compatibility with the context within which they are applied. In particular, the importance of knowing what is useful, and what is critical, to support the resilience of individuals, communities, and institutions. Specifically this perspective highlights the importance of local solutions generated by local stakeholders proactively dealing with local problems.

Alexander (2013) suggests there have been problems in making resilience a full-scale paradigm or even a science for a number of issues. For instance, some of the most cited definitions of 'resilience' have conceptualised the term quite differently depending on whether the 'system' is viewed as constant, stable, dynamic and/or has the capacity to adapt. To date, the typical definitions of resilience can be classified into four categories that are primarily focused upon:

- Resistance/robustness/absorption (e.g. Errington 1953; Holling 1973; Godschalk 2003; Salagnac 2013)

- Recovery/'bouncing back' - (e.g. Wildavsky 1988; Lindell and Perry 1992; Rose 2004)

- Planning/preparing/protecting - (e.g. Wildavsky 1988; Manyena 2006; Bosher 2008)

- $\quad$ Adaptive capacity - (e.g. Holling 1973; Folk 2006; UNISDR 2004; Wamsler and Lawson 2011; Vale 2013)

Therefore confusion about whether resilience is a process, a state or a quality has not helped resolve the understanding of how resilience can be best described (Reghezza-Zitt et al. 2012) and thus applied. Additionally, the use of resilience to describe homeostasis in systems is considered to be at variance with the 'resilience ideology' of people and communities that need to be protected-by means of dynamic changes (Reghezza-Zitt et al. 2012).

\section{'Built-in resilience'}

As a rejoinder to the concerns raised by Alexander (2013) and Reghezza-Zitt et al. (2012) and using Bosher's aforementioned 2008 definition of a resilient built environment, it is suggested that built-in resilience is a quality of a built environment's capability (in physical, institutional, economic and social terms) to keep adapting to existing and emergent threats. Therefore it is postulated that 'built-in resilience' can be a quality, a process and an end-state goal that can intuitively and proactively cope with dynamic changes (in their various natural and manmade guises). 


\section{Relevance of resilience to DRR}

It has been argued that the many professionals involved in the delivery and operation of the built environment need to become part of the paradigmatic shift from the previously reactive notions of 'disaster management' to the more proactive concept of 'disaster risk management' (Benson and Twigg 2007; Bosher et al. 2007). Although the concept of disaster risk management is traceable back to the beginning of the $20^{\text {th }}$ Century (Rollnick 2006), it has gradually become more institutionalised. This has in part been a product of social science research perspectives and 'resilience' debates leading to the realisation that the impact of a natural hazard mostly depends on the capacity of people to absorb the impact and quickly recover from loss or damage (cf. White 1945; Dynes and Quarentelli 1977; Maskrey 1989; Burton et al. 1993 and Wisner et al. 2004). The resultant shift in focus has been towards understanding social and economic vulnerability and has contributed to the move towards 'bottom-up', community based and sustainable long-term developmental initiatives related to Disaster Risk Reduction (DRR). DRR is thus defined by the United Nations as:

'The conceptual framework of elements considered with the possibilities to minimize vulnerabilities and disaster risks throughout a society, to avoid (prevention) or to limit (mitigation and preparedness) the adverse impacts of hazards, within the broad context of sustainable development.'

(UNISDR 2004)

Therefore, it is argued that if adopted holistically, DRR could be an effective way to increase resilience and specifically operationalise 'built-in resilience'.

However, despite the theoretical attractiveness of DRR, its effective delivery in practice is likely to be highly complex and in need of institutional and community support and guidance for those expected to enact it (Bosher and Dainty 2011). ${ }^{3}$ Therefore the socio-technical aspects that are required to suitably reflect the social and non-structural needs are particularly important for effective DRR and will for that reason be key components of the following discussion.

\section{DRR: a range of options}

Typically, effective risk management consists of five elements defined by the British Standards Institution (BSI), performed more or less, in the following order:

a) Identify, characterise, and assess natural hazards/ manmade threats

b) Assess the vulnerability of critical assets to specific hazards/threats 
c) Determine the risk (i.e. the expected consequences of specific hazards/threats on specific assets)

d) Identify ways to reduce those risks

e) Prioritise risk reduction measures (after BSI 2009)

It is beyond the scope of this paper to detail the wealth of approaches that can be used to effectively assess levels of risk. In simple terms, risk determination is achieved through the identification of the hazards/threats by assessing (qualitatively or quantitatively) the likelihood of something occurring (i.e. an earthquake or flood) and the potential consequences of those events occurring (i.e. significant loss of life, business disruption, damage to critical lifelines). To further complicate matters, it should also be recognised that dealing with 'known' risks arguably poses less ambiguities than dealing with other less apparent (or unknown) risks. Wildavsky (1988) made an interesting distinction between the different types of dynamic changes, namely anticipation (foreseeable) and resilience (unforeseen) that may be applicable to DRR. For instance it is likely that DRR may have most relevance to the structural and non-structural approaches (see Table 1 for some examples) required for dealing with 'foreseeable' risks (anticipation). However, the potential spin-off benefits of generating more resilient physical assets, communities, services, institutions etc. could become useful in creating the adaptive capacities required for dealing with any 'unforeseen' risks (resilience). It is therefore important to appreciate that DRR approaches may be limited because they will most likely primarily address the 'foreseeable' events (i.e. based upon rigours hazard/threat assessments) but there is potential that such approaches may engender a culture of resilience that will provide useful when dealing with any future unforeseen events (possibly related to any unforeseen impacts of climate change or new disease pandemics etc.). However, some pragmatic perspective should be used before becoming overly concerned about what might be termed unforeseen events (and particularly in relation to any 'Rumsfeldian' concerns about the socalled 'unknown unknowns'). ${ }^{4}$

Although it may be impossible to accurately predict every threat or hazard, it is arguably more important to recognise that too often disasters occur because risk reduction measures have not been considered or undertaken, despite there being prior knowledge of existing hazards and threats. ${ }^{5}$ Maybe it is the case that once societies have become more effective at dealing with the known risks, it will then be possible for those societies to put more effort into dealing with the less foreseeable risks. 
Central to this discussion is the realisation that much of the required information will need to be contextually specific. Therefore, local knowledge will be essential in the attainment of the appropriate determination of the risk levels and subsequent risk reduction options. If risk levels are deemed significant then there are a number of ways in which the risk can be eliminated, reduced, controlled or transferred. A hierarchy of typical risk reduction classifications (after Mansfield et al. 1996) includes:

\section{- Inherent safety:}

eliminate the possibility of hazards/threats occurring

- Prevention:

reduce the likelihood of hazards/threats occurring

- Detection:

measures for early warning of hazards

- Control:

limiting the size of the hazards

- Mitigation and adaptation:

proactive or retrospective protection from the effects of hazards

- Emergency response:

planning for evacuation and access for emergency services

These classifications are listed in an order of preference; given that ideally 'Inherent safety' should be a primary consideration, suggesting that the hazard/threat should be eliminated/avoided. For some hazards this can be possible (i.e. some floods and fires) but for others it is not possible unless built assets are relocated (i.e. away from areas prone to earthquakes, tsunamis and volcanic activity). By way of explanation, Table 1 lists some of the structural and non-structural risk reduction options relevant to addressing riverine flood risk, one of the most common natural hazards in England.

\section{[Take in Table 1]}

From the examples presented in Table 1 it is important to acknowledge that although some of these measures may be suitable for dealing with riverine flood risk, they may not be appropriate measures for other types of hazards or threats (for instance, seismic activity, severe storms or crime/terrorism prone locations). Consequently, multihazard/threat assessments should be undertaken and any risk reduction options should be proportionately considered alongside any other hazards or threats that have been identified. 
This leads to another key point. Potentially, a wide range of structural and non-structural risk reduction measures exist and can be adopted. Dependent upon the risk reduction measures chosen, there could be a complex range of stakeholders involved in the decision making processes required to achieve 'built-in resilience'. In theory the multistakeholder and multidisciplinary approaches encapsulated by the 'built-in resilience' concept and as advocated by DRR should provide suitable frameworks for addressing multiple hazards and threats.

\section{DRR and resilience in England}

Within England the resilience of the built environment has been given increasing attention over the past decade, with a range of non-legislative procedures and incentives. These measures could aid in reducing the vulnerability of the built environment to the plethora of hazards, threats and major accidents that pose a risk to it (Bosher et al. 2007). Advancements have occurred in recent years particularly in relation to the areas of emergency planning and urban planning, each of which are briefly explained in the next two sections.

\section{Emergency Planning}

England has a well-established system for emergency planning that is set out within the Civil Contingencies Act (CCA) 2004 (Civil Contingencies Secretariat 2004). The CCA, which is presently under review, has two parts: 1) local arrangements for civil protection and 2) emergency powers. The CCA stipulates two categories of front line 'responders' (category one and category two responders) and identifies their duties and responsibilities relating to 'localised incidents through to catastrophic events' (Civil Contingencies Secretariat 2004, p.2). 'Category One' responders, or 'core responders', are the emergency services, all principal local government authorities, National Health Service bodies and key government agencies. 'Category Two' responders comprise 'co-operating responders', that can consist of many private sector stakeholders such as utility companies, transport operators, and voluntary agencies. The CCA describes the duty of these 'responders' to cooperate in Local Resilience Forums (LRF), typically defined by police constabulary boundaries, to undertake risk assessments and carry out proactive risk reduction activities collaboratively.

\section{Local risk assessment}

Each local authority in England must produce a multi-hazard/threat risk assessment under the CCA. A two-way flow of information is required as local risk assessments are subsequently reviewed and in turn, fed back into a National 
Risk Assessment (NRA). The CCA also places a legal duty on local authorities and other key agencies to maintain the local risk assessments in a Community Risk Register (Cabinet Office 2010) that becomes the basis for supporting the preparation of emergency plans and, in theory but not necessarily in practice, for supporting appropriate decisions regarding urban planning. To illustrate the disparities between theory and practice an example will now be presented related to how flood risk and urban planning are generally considered in England.

\section{Insight into urban planning and flood risk}

Urban planning in England is highly regulated to the extent that the planning system has often been accused of constraining development and in some cases stymying private sector investments (see Balen 2006; Evans and Hartwich 2006). The publication of "Planning Policy Statement 25: Development and Flood Risk" (PPS25) by the Government was intended to ensure that flood risk is taken into account at all stages in the planning process. Specifically, it would avoid inappropriate development in areas at risk of flooding, and direct development away from areas at highest risk (DCLG 2006). Arguably this is a key consideration when attempting to attain built-in resilience; in simple terms it is about building appropriate things in appropriate locations. However, Crichton (2013) suggests that England's National Planning Policy Framework (NPPF), which was published in March 2012 and replaced most existing planning policy statements (including PPS25), means that there is no longer any clear guidance to prevent building in flood plains.

To further muddy the (flood) waters the 'Growth and Infrastructure Act' (2013), sets out to release large areas of greenfield land for development, especially in the South of England. The Act effectively gives developers a right to submit major planning applications directly to central government. Thus proposals and decisions evade not only communities but also local planning authorities (Crichton 2013). As a result of these recent legislative changes, there is now a higher likelihood that inappropriate buildings could be built in inappropriate locations.

\section{Observed improvements to flood risk?}

It has been observed that agreements between the government and the insurance industry have left an increasing number of vulnerable people in England without adequate cover against natural hazards such as flooding (Wamsler and Lawson 2011). Until recently there was an agreement in place between the Government and the insurance industry, called the 'Statement of Principles' that obliged insurance companies to offer coverage for floods as part of standard policies in most cases. The agreement was renegotiated between the Associate of British Insurers and the 
Government in June 2013 and a 'Memorandum of Understanding' was agreed on how to develop a not-for-profit scheme called 'Flood Re' that would ensure flood insurance remains widely affordable and available (ABI 2013). Therefore, while these types of agreements are in place it means that many properties in flood prone areas have received flood cover as a standard component of their household insurance cover. This may act as a disincentive for private property owners to proactively address or avoid flood risk (Cabinet Office 2008).

The continued development of flood plains in England has had an effect that has not really been fully appreciated by the English government. For instance, Crichton (2008) states that 'property developers' are increasingly using flood plains to build social rented housing for low-income families, homes for the elderly/disabled as well as schools and hospitals; to the extent that it is claimed that there are over 2,000 schools and 80 hospitals in flood hazard areas in England (Crichton 2008). This indicates that the legacy of planning policy and insurance practice in England have contributed to creating urban areas where some of the most vulnerable members of society (i.e. children, the elderly and the ill) inhabit highly flood prone areas and, in some cases, do not possess adequate insurance cover. In the wake of the 2007 floods in England, the government's subsequent report noted that the residents of social housing are often the least resilient and are most unlikely to have insurance (Cabinet Office 2008).

Despite a plethora of guidance for planners and apparent restrictions for developers, it appears that the development of flood prone areas in England persists and in some regions has actually increased (DCLG 2011). Table 2 shows Government figures for the percentages of new dwellings ${ }^{6}$ built within areas of high flood risk $^{7}$ between 1989 and 2010 (DCLG 2011). The average proportion of new dwellings built in areas of high flood risk has fluctuated annually between $7 \%$ and $11 \%$ with some regions such as London, Yorkshire and Humber and the East Midlands regularly surpassing these averages. The consequence of this is that on average nearly 1 in every 10 new dwellings is built in flood prone areas in England. In real terms this equates to approximately between 10,000 (based upon the 102,830 dwellings built in 2010) ${ }^{8}$ and 17,000 (based upon the 175,560 peak of dwellings built in 2007) ${ }^{9}$ dwellings being built in high flood prone areas every year for the last two decades. However, it should be noted that there have been some more positive results in the reduction of the amount of developments being built in 'Very significant flood risk areas' (greater than 1 in 20 year return) and 'Significant flood risk areas' (greater than 1 in 75 year return) as defined by another Government agency, namely the Environment Agency (EA 2011). ${ }^{10}$

[Take in Table 2] 
The figures in Table 2 suggest that the publication of PPS25 in 2006 had a negligible impact in reducing the proportion of dwellings being built in flood prone areas. Hence PPS 25 has been criticised because it could permit development in flood plains if it was perceived that there was nowhere safer to build through an approach called 'The Sequential Test' (Crichton 2012). The planning policy requires Local Planning Authorities (LPA) to apply a sequential approach as part of the identification of land for development to determine areas of risk of flooding but it can be abused, as explained during an interview with an insurance expert:

"In practice this test can be, and has been, used by developers to get permission to build in flood prone areas because they have argued that there are no non-flood prone areas available to build upon. This argument has increasingly been used successfully to get planning permission in Greater London."

(Insurance and Flood Risk practitioner, London)

\section{Involving public and private sector stakeholders in DRR}

The Concept paper for the fourth session of the Global Platform for DRR (UNISDR 2012) states that approximately $85 \%$ of all investments worldwide stem from the private sector, including large companies but also small and medium enterprises and individual investors. The private sector therefore has been identified as playing an important role in helping to incorporate DRR into the development (and redevelopment) of communities across the world. The important role of the private and private/public sectors in England has also been identified by Bosher et al. (2009) when mapping out the main types of stakeholders that should be involved with DRR in construction projects and also when their optimal inputs should be made (see Appendix 1). The key messages from the matrix shown in Appendix 1 are a) there are many stakeholders that should/could be more involved in DRR related activities and b) that specific stakeholder optimal inputs should be targeted at times when the inputs can be most relevant - specifically in the design and planning stages. This may sound like an obvious statement but many risk managers and emergency planners consulted as part of this research reported that their inputs on any DRR related matters (i.e. flood defences, Sustainable Urban Drainage Systems (SuDS), Crime Prevention Through Environmental Design and Counter Terrorism design features) tended to be requested far too late in the process (i.e. when everything was planned, designed and the construction was nearing completion).

This apparent disconnect between those that should be making DRR related decisions and the reality of the design, planning, construction, operation and maintenance process is illustrated in Appendix 2 that shows (in contrast to the 
matrix in Appendix 1) the stakeholders that are currently involved in England. As a consequence of this disconnect, many DRR related measures are not considered or become afterthoughts and thus more expensive and less effective. The disparity between 'those that should' and 'those that do' undertake DRR related interventions in England demonstrates that without strong (and suitably enforced) regulatory measures, ownership of the problems associated with disaster risk are unlikely to be taken seriously.

Another pertinent observation from Appendices 1 and 2 is that private and private/public sector stakeholders (for instance, clients and architects) have a potentially critical role to play in whether or not DRR is incorporated into urban developments. It has been assessed that inputs from the private and private/public sector stakeholders are particularly important during pre-project and pre-construction stages where structural and non-structural DRR consideration can be most effectively incorporated (from a cost and performance perspective) into new developments or the redevelopment of existing sites (Bosher et al. 2009).

Recent research (see Johnson et al. 2013; UNISDR 2013b; Bosher and Dainty 2011) suggest that from the private sector, developers and clients are central to either helping or hindering the integration of DRR. However, discussions conducted during this study with representatives of the private housing sector in England indicate that the sector is not interested in adopting DRR measures unless these are regulated or at least incentivised through insurance benefits or a clear business case. This stance has apparently been aggravated by the Government's announcement in 2010 that it did not intend to change building standards to require new homes to be more resilient to storm or flood damage. At a time of economic recession it is therefore understandable that most private sector companies will need to focus upon minimising the financial risks of development projects; a point articulated during an interview with the director of a construction company:

"From a business point of view we need to ensure that we do not 'scare off' the developer or client by saying we will be considering hazard mitigation issues. Nine times out of ten the developer or client will assume these measures will cost them more money; so they may ditch us and go for the company that they perceive as being better value for money, or in other words is perceived to be the 'cheapest' option. The developers and clients are the "keystones" to the attainment of built-in resilience."

(Director, international construction company) 


\section{Summary of the problems}

This discussion has so far highlighted that despite the introduction of a clear framework (the CCA 2004 and specific planning policy such as PPS25) that was aimed to encourage 'built-in resilience', the impact has so far been limited particularly in relation to addressing flood risk. This apparent lack of success could be summarised as being attributed to six key factors:

\section{- Legacy of poor urbanisation}

A long-term legacy of inappropriate urbanisation has occurred over the last 50-100 years. This development has resulted in issues such as poorly located privately owned/operated critical infrastructure and housing.

\section{- Climate change impacts}

The observed impacts of a changing climate can put increased stresses upon the built environment. The impacts may include increased storminess, more frequent intensive rainfall events and prolonged periods of drought (Defra 2012).

\section{- Inappropriate governance}

Although legislation (CCA 2004) provides an explicit framework to help operationalise DRR, the decision to devolve powers to local public sector authorities and representatives of key private sectors organisations is problematic. It effectively shifted the 'responsibility' (to take action) but not the 'blame' (if anything goes wrong). Another key problem is the emphasis on 'planning to respond' to emergency events rather than 'planning to reduce or eliminate' the emergency events. Legislation can also have a very negative impact on flood risk if it allows flood prone land to be used for the construction of houses and infrastructure (i.e. NPPF and the Growth and Infrastructure Act); especially if no efforts are subsequently made to make the housing or infrastructure resistant or resilience to flood impacts.

\section{- Limited awareness of actors' roles}

There is a vast range of construction and non-construction stakeholders (from the private and public sectors) that need to be better engaged in DRR initiatives and made more aware of the benefits of 'built-in resilience'. Currently, very few of these professionals recognise or acknowledge DRR as being an integral part of their day-to-day decision making. This is partially related to the professional training of disciplines such as civil engineers, architects and urban planners as DRR has not been considered a core skill of these professions.

\section{- Poor timing of key decisions}

If any DRR related options are considered at all, they tend to be considered too late in the planning, design, construction and operation process. For instance when construction has already started on 'new builds' or for 
existing developments after a disastrous event has already occurred. The result is that any resultant DRR interventions tend to be more costly and less effective. This problem can be exacerbated in the post-disaster context when there tends to be political pressure for affected areas to be rehabilitated too quickly and often without suitable allowances made to incorporate DRR measures (cf Vale 2013).

\section{- Unclear responsibilities}

To further complicate matters, an increasing proportion of England's urban areas possess privately-ownedpublic-places. The CCA 2004 places a responsibility for local authorities to increase local resilience (physical, social, organisational and environmental aspects). However many of the key stakeholders that are required to support this work are private sector companies who, as previously indicated, do not necessarily possess the appetite to invest in such measures unless there is a clear incentive to do so.

\section{Some ways forward}

The incorporation of 'resilience' into everyday practice in England has too often been an agenda which has been driven mainly by politicians and emergency planning professionals with little, if any, discussion with citizens, the business community, town planners, urban designers, and other built environment professionals (Coaffee 2008). There is a need to engender a concept of resilience that encourages individuals and society to adapt (pro-actively) to macro level issues such as climate change. There is broad acceptance in government and civil society that climate change is already happening. This implies a need to adapt the way citizens live their lives (at the individual, household, community, town, regional, country levels). This adaptation will need to incorporate the physical, natural, institutional, economic, educational, community/social and individual components of resilience. With a particular relevance to 'new builds', a range of strategies are required to help attain improved social, physical and institutional resilience to a diversity of hazards and threats. These measures are likely to include:

\section{- Revisions to building codes}

The required revisions will necessitate investment in generating and utilising more research based evidence that encompasses a range of structural and non-structural approaches to addressing multiple hazards. ${ }^{11}$

\section{- Tightening of planning policy}

A strong political will is required (at all levels of governance) to think and act for the long-term (i.e. 25-100 year time scales) and move away from the 'Not In My Term of Office' (NIMTOFF) attitude. Rather than relying on a 'top down' approach, Flood Liaison and Advice Groups (FLAGS) could be a useful 'bottom-up' approach to tightening planning policy. FLAGS provide a network in Scotland through which stakeholders have an 
opportunity to influence local policies, and advise local planners and have been fundamental to the Scottish strategy of flood risk reduction (Crichton, 2008). In England a number of Flood Action Groups have been established but they have so far yet to achieve the status and influence that the FLAGS in Scotland have attained.

\section{- Encouraging a socio-technical systems approach}

Good practice guidance is needed on the broad range of structural and non-structural risk reduction measures. This responsibility also partially falls on the general public. For instance, people that buy or rent houses and the extent to which they are aware of the hazards that may affect their homes. For a start, the way that information is provided to the general public could be improved and made more accessible. For example in relation to flood risk, a '1:100 year flood return' is incorrectly interpreted by many people to mean something that is unlikely to happen in their life time. This could be rephrased as "in the next 25 years there is a greater than 1:5 chance of experiencing one flood in your house".

\section{- Improvements to professional training}

As advocated by Russell (2013) and Janda and Pareg (2013) new skills are required as core competencies to enable a better understanding of the societal aspects of their profession and improved engagement lempowerment with stakeholders (such as clients and the local community).

It is therefore important that the wide range of built environment professionals (as listed in Appendix 1) are consulted and actively involved in the strategies that will be required to make built assets more resilient to natural hazards and manmade threats. While admittedly this is not a panacea it would definitely be a move in the right direction.

\section{Concluding observations}

\section{What is built-in resilience?}

Alexander's review of the etymological basis for 'resilience' suggests that it is not always clear what resilience is but concludes that:

"Resilience is a multi-faceted concept that is adaptable to various uses and contexts, but in different ways. As a concept, resilience shows promise in that it encourages the researcher to bridge the "shear zone" between (dynamic) adaptation and (static) resistance."

(Alexander 2013: 1273) 
In an attempt to help bridge this theoretical and operational "shear zone" this paper suggests that built-in resilience is a quality, a process and an end-state goal; arguably the quality is the ability to intuitively and proactively cope with a broad range of dynamic changes. However, while this definition of the built-in resilience concept may be pertinent and indeed useful for promoting a range of DRR activities it is most likely the case that other (possibly more simplistic or myopic) conceptualisations of 'resilience' often prevail. This lack of clarity and broad agreement may result in rendering the concept meaningless operationally. As Vale puts it, "the term resilience may collapse into the meaninglessness that results from having too many meanings". (Vale 2013:XX).

\section{Engendering a culture of resilience}

Although it may be impossible to accurately predict everything, it is more important to recognise that disasters often occur because risk reduction measures have not been considered or undertaken, despite there being prior knowledge of existing hazards and threats. DRR approaches may be limited because they primarily address the 'foreseeable' events. However, such approaches may engender adaptive capabilities that can prove useful when dealing with any future unforeseen (natural or manmade) events. When societies become more effective at dealing with the known or anticipated risks, it is expected that this may stimulate a 'culture of resilience and adaptability' that can enable them to deal with less foreseeable events.

The idea of societies being able to generate a culture that can adapt to survive internal and external threats is not new. Indeed there are relevant lessons from previous European societies. Gerrard and Petley (2013) claim that evidence exists to support the view that European societies in the Middle Ages (1000-1550AD) were quite advanced in developing sophisticated measures (structural and non-structural) to cope with natural hazards such as floods and earthquakes. If this was the case, have modern (more urbanised) societies lost these capabilities to adapt? Unfortunately the scientific community's ability to measure the extent to which such a culture of resilience and adaptability has been, or can be, stimulated (in households, neighbourhoods, societies, cities, businesses, government departments etc.) in modern societies has so far been rather limited. This poses an on-going research challenge.

\section{DRR: a bottom-up approach}

It is argued that if adopted holistically, DRR could be an effective way to operationalise 'built-in resilience' and attain a more resilient built environment (see Wamsler 2006; Twigg 2007; Bosher and Dainty 2011). Encouraging a wide 
range of stakeholders to proactively integrate DRR and 'resilience' considerations into the (re)development of the built environment is thus frequently being promoted but in reality is often stymied by a range of operational issues that have raised a number of research challenges as summarised in Table 3. Of particular importance is the need to develop (or adapt existing) urban multi-hazard/threat risk assessment methodologies so that the potential 'spin-off benefits' of dealing with different hazards can be maximised (i.e. flood risk management approaches that also provide benefits to increased security and/or sustainability) and any clashes can be minimised.

\section{[Take in Table 3]}

Some of the operational issues highlighted earlier in this paper and the research challenges detailed in Table 3 indicate that the private sector has a critical role to play in the built-in resilience process and end-state. The realities of free-markets economics (i.e. the valuation of flood prone land and the competitive market for insurers to provide flood insurance as standard) and the lack of incentives for the private (and even the public-private) sector to proactively consider DRR on developments have resulted in a legacy of inappropriately conceived developments. To exacerbate matters, the recent changes to top-down strategies associated with building regulations and planning policy may actually make it easier to build inappropriate buildings and assets in inappropriate locations. These changes have occurred to promote economic development, but not necessarily to enable appropriate economic development.

Nonetheless, there is scope for utilising a 'bottom-up' approach to advance the built-in resilience issue. For instance, possibly through forward thinking private sector developers that can grasp the business opportunity (even if it is just driven by free-market fundamentalism). For some 'new build' developments, particular developers are recognising that it could actually be a good idea to become a market leader in incorporating DRR into commercial developments with the hope that it will give them the cutting edge over competitors in the short term (i.e. under current legislative conditions) and the long term (see UNISDR 2013b for some specific examples). Of course, this will all need to be supported by many other non-structural activities such as, and not limited to, incorporating DRR into the professional training (formal and informal) of built environment professionals and raising awareness of proactive risk reduction to deal with the current and longer-term impacts of climate change. 


\section{Is 'built-in resilience' a suitable lens?}

It has been suggested that built-in resilience is a quality, a process and an end-state goal with the 'quality' being the ability to intuitively and proactively cope with a comprehensive range of dynamic changes. This vision of built-in resilience ties together many previous conceptualisations of resilience incorporating the robustness/resistance, recovery, preparedness and adaptive aspects. This vision proposes that a broad range of structural and nonstructural approaches are required, involving many key stakeholders/disciplines to operationalise the concept. The multiple stakeholder and multi-disciplinary requirement of 'built-in resilience' should provide an effective framework for helping to address the challenges associated with dealing with multiple threats. However the richness and complexity associated with using the 'built-in resilience' lens will undoubtedly be problematic to operationalise.

Fundamentally, an important tension is revealed in this paper. 'Human agency' is often weak in understanding and addressing resilience and henceforth there is a need to create planned or engineered solutions to reduce exposure to risks. Conversely, it is also the case that human planning and decision making (professionally and institutionally) has been weak in establishing and maintaining these plans and solutions. Consequently, many of the research challenges (identified in Table 3) about attaining built-in resilience are primarily about addressing the non-structural issues and less about generating structural solutions per se.

Bosher et al. (2007) made a number of recommendations related to structural and non-structural approaches towards built-in resilience. The authors concluded that "ultimately, many of these recommendations may need to be driven by legislative change" (Bosher et al. 2007: 176). Since that (on reflection overly) optimistic statement, the legislative landscape in England has indeed changed but arguably in a way that could make the built environment less resilient. Unfortunately, this demonstrates that the non-structural measures associated with regulations and planning guidance can end up providing a disabling environment that cannot stimulate the culture of resilience required to attain resilient built environments.

Operationally, it might appear that the lens of 'built-in resilience' is too nebulous, multi-facetted and complex to warrant effective application in the real world, or at least in England. 'Built-in resilience' requires a holistic overarching strategy, but the example of the English government has shown the difficulties and adverse drivers for achieving this. The recent approaches to increasing resilience in England have not really been able to intuitively and proactively cope with well-established problems such as flood risk. This is because currently the resilience agenda in England is 
dominated by activities that are too focused on 'preparing to respond' rather than the more proactive, preventative and adaptive measures encompassed within the 'built-in resilience' concept. If the wrong type of resilience lens is used (i.e. one that is too focused on the resistance and recovery aspects of resilience) then the result is a myopia where key stakeholders such as planners and developers are not recognised as being part of the problem, or indeed part of the solution.

'Bottom up' DRR approaches may provide small or short-term solutions but these need to be supported by 'top down' initiatives. 'Built-in resilience' has the potential to be a concept that can help to integrate and support a wide range of DRR activities (structural and non-structural) but this is only possible with concerted top-down strategic action. Only when the complexities of 'built-in resilience' are embraced and used to develop long-term strategic joined-up thinking, and hence joined-up actions, will it be possible for the 'resilience' concept to serve as a vital bridge, both in theoryand more importantly—in practice.

\section{ACKNOWLEDGEMENTS}

This paper is based upon a working paper that was presented at the 'Resilience and the Built Environment Workshop', hosted by ETH in Zurich in January 2013. The author wishes to thank the organisers and all the participants at the workshop for their very helpful comments on the working paper. Thanks also go to the anonymous reviewers that provided constructive comments that have helped the author to clarify points and finesse the content of the paper.

\section{FUNDING}

The author is also grateful for the financial support that has partially supported this research received from the European Commission $7^{\text {th }}$ Framework Project (FP7-SEC-2010-1) DESURBS (Designing Safer Urban Spaces) Project Number: 261652.

\section{REFERENCES}

$A B I$ (2013), 'ABI and Government agree Memorandum of Understanding on scheme to safeguard UK flood insurance', Press release $9^{\text {th }}$ August 2013, Association of British Insurers (ABI), London

Alexander D. E., (2013), 'Resilience and disaster risk reduction: An etymological journey', Natural Hazards and Earth System Sciences, Vol.1: 1257-1284

Balen M. (2006), Land economy, Institute of Economic Affairs, London 
BBC, (2012), 'Flood defences: Praise and criticism of new schemes', BBC Online, Available http://www.bbc.co.uk/news/uk-england-20487648 (Accessed 27th November 2012)

Blum J.L., (1968) 'Salt Marsh Spartinas and Associated Algae', Ecological Monographs, 38(3): 199-221

Benson C. and Twigg J., (2007), Tools for Mainstreaming Disaster Risk Reduction: Guidance Notes for Development Organisations, International Federation of the Red Cross and Red Crescent Societies/The ProVention Consortium, Geneva

Bosher L.S., (ed.), (2008) Hazards and the Built Environment: Attaining Built-in Resilience, Taylor and Francis, London

Bosher L.S. and Dainty A.R.J., (2011) 'Disaster risk reduction and 'built-in' resilience: Towards overarching principles for construction practice', Disasters, 35(1): 1-18

Bosher L.S., Dainty A.R.J., Carrillo P.M., Glass J., and Price A.D.F., (2009), 'Attaining improved resilience to floods: A proactive multi-stakeholder approach', Disaster Prevention and Management, 18(1): 9-22

Bosher L.S., Dainty A.R.J., Carrillo P.M., Glass J., and Price A.D.F., (2007) 'Integrating disaster risk management into construction: A UK perspective', Building Research and Information, 35(2):163-177

British Standards Institution, (2009), Risk Management: Principles and Guidelines, London: British Standards Institution Group

Burton I., Kates R.W., and White G., (1993) The Environment as Hazard: Second Edition, Guilford Press, London

Cabinet Office, (2010), National Risk Register of Civil Emergencies 2010 edition, HMSO, London

Cabinet Office, (2008), Learning lessons from the 2007 floods: An independent report by Sir Michael Pitt, Cabinet Office, London

Civil Contingencies Secretariat, (2004), Civil Contingencies Act 2004, Cabinet Office, London

Coaffee J., (2008), 'Security planning in the resilient city: Stimulating integrated emergency planning and management' in Bosher L.S., (ed.), (2008), Hazards and the Built Environment: Attaining Built-in Resilience, Taylor and Francis, London: 300-316

Comfort L.K., (1994), 'Risk and Resilience: Inter-organizational Learning Following the Northridge Earthquake of 17 January 1994', Journal of Contingencies and Crisis Management, 2(3):174-188

Crichton D., 'Flood risk: Planning in England and Wales', in CII, (2013), Upon the door of every cottage: Protecting the public through general insurance, Chartered Insurance Institute (CII), London

Crichton D., (2012), Flood plain speaking, The Chartered Insurance Institute, London Available http://www.cii.co.uk/knowledge/claims/articles/flood-plain-speaking/16686 (Accessed $20^{\text {th }}$ September 2012)

Crichton D., (2008), 'Role of insurance in reducing flood risk', The Geneva Papers, 33: 117-32

DCLG (2011) 'Table P251 Land Use Change: Percentage of new dwellings built within areas of high flood risk, by region, 1989 to 2010', Live tables on land use change statistics, Department for Communities and Local Government, London.

DCLG (2006), Planning Policy Statement 25: Development and Flood Risk, Department for Communities and Local Government, London

Dynes R. and Quarantelli E. L., (1977) Organisational Communications and Decision-making in Crises, Report, Series 17, Disaster Research Centre, Ohio State University, Columbus

EA (2011), Flood and coastal erosion risk management progress report 2008-2011 for England, Environment Agency, Bristol

EERI, (2006), 'The Kashmir Earthquake of October 8, 2005: Impacts in Pakistan', EERI Special Earthquake Report February 2006, Oakland, USA: Earthquake Engineering Research Institute.

Errington P.L., (1953) 'Reviewed Work(s): Natural Communities by Lee R. Dice'. Science, New Series, 117(3028): p.43

Evans A. and Hartwich O., (2006), Better homes, greener cities, Policy Exchange, London 
Folke C., (2006), 'Resilience: The emergence of a perspective for social-ecological systems analyses', Global Environmental Change, 16(3): 253-267

Gerrard C. M. and Petley D. N., (2013), 'A risk society? Environmental hazards, risk and resilience in the later Middle Ages in Europe', Natural Hazards, 69: 1051-1079

Godschalk D., (2003), 'Urban Hazard Mitigation: Creating Resilient Cities'. Nat. Hazards Rev., 4(3): 136-143.

Green B., (2011), 'England sees 102,830 new homes built in 2010 - we built more in 1875', Building Magazine, $17^{\text {th }}$ February, Available on-line http://www.building.co.uk/england-sees-102830-new-homes-built-in-2010\%E2\%80\%93-we-built-more-in-1875/5013562.blog (Accessed 12th February 2013)

Holling, C. S., (1973), 'Resilience and stability of ecological systems', Annual Reviews of Ecological Systems, 4, 1-23

Hollnagel, E. (2013). 'Resilience engineering and the built environment'. Building Research \& Information. 42(2).

Hollnagel E. Woods D.D. and Leveson N., (eds.) (2006) Resilience Engineering: Concepts and Precepts, Ashgate Publishing, Aldershot

Hynes W., and Purcell S. M., (2012), 'Security for Critical Infrastructure and Urban Areas: A Holistic Approach to Urban Safety, Security and Resilience'. In: Future Security, Springer Berlin Heidelberg: pp. 165-175

Jabareen Y., (2012), 'Towards a Sustainability Education Framework: Challenges, Concepts and Strategies - The Contribution from Urban Planning Perspectives'. Sustainability, 4(9): 2247-2269

Janda, K.B. and Parag, Y. (2013). A middle-out approach for improving energy performance in buildings. Building Research \& Information, 41(1), 39-50

Johnson C., Bosher L., Adekalan I., Jabeen H., Kataria S., Wijitbusaba A. and Zerjav B., (2013), 'Private sector investment decisions in building and construction: increasing, managing and transferring risks'. Working paper for the Global Assessment Report 2013 on Disaster Risk Reduction, UNISDR, Geneva, Switzerland

Lindell, M.K. and Perry R.W., (1992), Behavioral foundations of community emergency planning, Hemisphere Publishing Corp, Washington

Madni A.M., (2007), 'Designing for Resilience', ISTI Lecture Notes on Advanced Topics in Systems Engineering, University of California at Los Angeles (UCLA)

Madni A.M. and Jackson S., (2009), 'Towards a conceptual framework for resilience engineering', IEEE Systems Journal, 3(2): 181-191

Mansfield D., Poulter, L. and Kletz T.A., (1996), Improving Inherent Safety, HSE Books, Sudbury

Manyena S.B., (2006) 'The concept of resilience revisited', Disasters, 30(4): 433-450

Maskrey A., (1989) Disaster Mitigation: A Community Based Approach, Oxfam, Oxford

Ramseh R., (2012), 'Government 'failing to get enough homes built', The Guardian, London, $17^{\text {th }}$ May

Reghezza-Zitt, M., Rufat, S., Djament-Tran, G., Le Blanc, A., and L'Homme, S., (2012) 'What resilience is not: Uses and abuses', CyberGeo, 621: 1-23

Rollnick R., (2006) 'The aftermath of natural disasters and conflict', Habitat Debate, 12(4): 4-5

Rose A., (2004) 'Defining and Measuring Economic Resilience to Disasters,' Disaster Prevention and Management, 13(4): 307-14

Russell, J. S. (2013), 'Shaping the Future of the Civil Engineering Profession', Journal of Construction Engineering and Management, 139(6): 654-664

Salagnac, J-L., (2013), 'Urban resilience: an operative concept?', Resilience and the Built Environment Workshop, ETH, Zurich 14-15th January 2013

UNISDR, (2013a), 'Disaster statistics', United Nations International Strategy for Disaster Reduction Secretariat, Geneva Available on-line http://www.unisdr.org/we/inform/disaster-statistics (Accessed 12th February 2013)

UNISDR, (2013b), Global Assessment Report 2013 on Disaster Risk Reduction, UNISDR, Geneva, Switzerland 
UNISDR, (2012), Concept note: Fourth session of the Global Platform for Disaster Risk Reduction, United Nations International Strategy for Disaster Reduction Secretariat, Geneva

UNISDR, (2011), Global Assessment Report on Disaster Risk Reduction: Revealing Risk, Redefining Development. United Nations International Strategy for Disaster Reduction, Geneva

UNISDR, (2004) Living with Risk: A Global Review of Disaster Reduction Initiatives, United Nations International Strategy for Disaster Reduction, Geneva

Defra, (2012), The UK Climate Change Risk Assessment 2012 Evidence Report, Department for Environment, Food and Rural Affairs (Defra), London

Vale L.J., (2013), 'Resilient Cities: Whose Resilience? Whose City?', Building Research \& Information. 42(2).

Vale L.J. and Campanella T.J., (eds), (2005) The Resilient City: How Modern Cities Recover from Disaster, Oxford University Press, Oxford

Wamsler C., (2006) 'Mainstreaming risk reduction in urban planning and housing: A challenge for international aid organisations', Disasters, 30(2): 151-177

Wamsler C. and Lawson N., (2012), 'Complementing institutional with localised strategies for climate change adaptation: A South-North comparison'. Disasters, 36(1): 28-53

Wamsler C. and Lawson N., (2011) 'The role of formal and informal insurance mechanisms for reducing urban disaster risk: A south-north comparison', Housing Studies, 26(2): 197-223

White G.F., (1945) Human adjustment to floods. Research Paper 29. Department of Geography, University of Chicago, 225 pp.

Wildavsky A., (1988) Searching for Safety, New Brunswick, NJ: Transaction Press

Williams S. and Jacobs K., (2011), 'Introduction: Disasters, housing, actuarialism and the securitisation of risk', Housing Studies, 26(2): 185-195

Wisner B., Blaikie P., Cannon T. and Davis I., (2004) At Risk: Natural Hazards, People's Vulnerability, and Disasters, second edition, Routledge, London 
Table 1: Structural and non-structural risk reduction options (non-exhaustive) that might be used to address 'Riverine flooding'

\begin{tabular}{|c|c|c|c|}
\hline \multicolumn{2}{|c|}{$\begin{array}{l}\text { Risk reduction } \\
\text { option }\end{array}$} & Structural examples & Non-Structural examples \\
\hline 1) & $\begin{array}{l}\text { Inherent safety - } \\
\text { eliminate the } \\
\text { possibility of } \\
\text { hazards occurring }\end{array}$ & $\begin{array}{l}\text { Do not create 'new land' in natural wetlands (i.e. the } \\
\text { polders in the Netherlands) }\end{array}$ & $\begin{array}{l}\text { Do not build within the flood plain or on land } \\
\text { adjacent to flood risk areas } \\
\text { Avoid redirecting/re-engineering the course } \\
\text { of rivers (i.e. Mississippi River, USA) }\end{array}$ \\
\hline 2) & $\begin{array}{l}\text { Prevention - } \\
\text { reduce the likelihood } \\
\text { of hazards }\end{array}$ & $\begin{array}{l}\text { If environmentally appropriate build dams to } \\
\text { moderate fluctuations in river flows. } \\
\text { Managed retreat of development from flood } \\
\text { threatened areas }\end{array}$ & $\begin{array}{l}\text { Encourage natural barriers to grow/thrive } \\
\text { (wetlands and mangroves) } \\
\text { Discourage residents to pave over gardens }\end{array}$ \\
\hline 3) & $\begin{array}{l}\text { Detection - } \\
\text { measures for early } \\
\text { warning of hazards }\end{array}$ & River level gauges (with automated alarms) & $\begin{array}{l}\text { Weather forecasting (using satellite imagery) } \\
\text { Local knowledge and flood warnings } \\
\text { Education and awareness raising of flood } \\
\text { risk (in local schools and communities) }\end{array}$ \\
\hline 4) & $\begin{array}{l}\text { Control - limiting } \\
\text { the size of the } \\
\text { hazards }\end{array}$ & $\begin{array}{l}\text { Protect natural river levees and/or flood plains } \\
\text { Manmade flood defences/walls/gates/ditches (i.e. } \\
\text { dykes in the Netherlands and drainage canals in } \\
\text { Los Angeles) } \\
\text { Sustainable urban drainage systems (SUDS), } \\
\text { swales and retention ponds }\end{array}$ & $\begin{array}{l}\text { Land use zoning } \\
\text { Strong regulations to support proactive flood } \\
\text { risk management and inappropriate } \\
\text { development } \\
\text { Reduced insurance premiums for people that } \\
\text { use flood risk reduction defences }\end{array}$ \\
\hline 5) & $\begin{array}{l}\text { Mitigation and } \\
\text { adaptation - } \\
\text { providing protection } \\
\text { from the effects of } \\
\text { hazards }\end{array}$ & $\begin{array}{l}\text { Localised flood defences/walls/gates } \\
\text { Flood resilience/resistant materials for buildings } \\
\text { Adapting/retrofitting existing buildings and } \\
\text { infrastructure to include hazard mitigation features } \\
\text { Permanent flood resistant defences for buildings } \\
\text { Amphibious buildings } \\
\text { Buildings/roads built on stilts } \\
\text { Non-return valves on sewer pipes }\end{array}$ & $\begin{array}{l}\text { Land use zoning } \\
\text { Car parking spaces provided on the ground } \\
\text { floor } \\
\text { Demountable and temporary flood defences }\end{array}$ \\
\hline 6) & $\begin{array}{l}\text { Emergency } \\
\text { response - } \\
\text { planning for } \\
\text { evacuation } \\
\text { emergency access }\end{array}$ & $\begin{array}{l}\text { Building critical infrastructure and emergency } \\
\text { services/resources in safe/protected areas }\end{array}$ & $\begin{array}{l}\text { Land use zoning } \\
\text { Emergency planning and establishment of } \\
\text { 'Local resilience forums' } \\
\text { Local initiatives (such as Flood Liaison and } \\
\text { Advisory Groups) } \\
\text { Evacuation route planning \& evacuation } \\
\text { testing }\end{array}$ \\
\hline
\end{tabular}


Table 2: Land Use Change in England: Percentage of new dwellings built within areas of high flood risk, by region, between 1989 to 2010

\begin{tabular}{|c|c|c|c|c|c|c|c|c|c|c|}
\hline \multirow[b]{2}{*}{ Year } & \multicolumn{9}{|c|}{ Regions of England } & \multirow{2}{*}{$\begin{array}{l}\text { Percentages } \\
\text { England }\end{array}$} \\
\hline & $\begin{array}{c}\text { N. } \\
\text { East }\end{array}$ & $\begin{array}{c}\text { N. } \\
\text { West }\end{array}$ & $\begin{array}{l}\text { Yorks \& } \\
\text { Humber }\end{array}$ & $\begin{array}{l}\text { East } \\
\text { Mids. }\end{array}$ & $\begin{array}{l}\text { West } \\
\text { Mids. }\end{array}$ & $\begin{array}{l}\text { East of } \\
\text { England }\end{array}$ & London & $\begin{array}{c}\text { South } \\
\text { East }\end{array}$ & $\begin{array}{l}\text { South } \\
\text { West }\end{array}$ & \\
\hline 1989 & 1 & 4 & 11 & 13 & 3 & 7 & 17 & 8 & 7 & 8 \\
\hline 1990 & 1 & 4 & 13 & 12 & 2 & 6 & 16 & 7 & 6 & 7 \\
\hline 1991 & 2 & 3 & 15 & 8 & 5 & 4 & 13 & 5 & 5 & 7 \\
\hline 1992 & 5 & 3 & 11 & 7 & 4 & 5 & 19 & 6 & 7 & 7 \\
\hline 1993 & 1 & 4 & 10 & 12 & 4 & 4 & 15 & 6 & 5 & 7 \\
\hline 1994 & 2 & 4 & 10 & 9 & 4 & 5 & 17 & 6 & 8 & 7 \\
\hline 1995 & 4 & 3 & 11 & 10 & 3 & 5 & 21 & 6 & 7 & 8 \\
\hline 1996 & 2 & 2 & 9 & 10 & 4 & 4 & 25 & 5 & 7 & 7 \\
\hline 1997 & 3 & 2 & 9 & 11 & 4 & 7 & 24 & 6 & 9 & 8 \\
\hline 1998 & 1 & 3 & 6 & 4 & 4 & 5 & 23 & 7 & 7 & 7 \\
\hline 1999 & 2 & 3 & 9 & 7 & 4 & 6 & 24 & 7 & 8 & 8 \\
\hline 2000 & 1 & 5 & 11 & 9 & 2 & 6 & 22 & 7 & 8 & 8 \\
\hline 2001 & 2 & 5 & 11 & 10 & 3 & 5 & 18 & 7 & 9 & 8 \\
\hline 2002 & 2 & 4 & 11 & 12 & 3 & 7 & 20 & 6 & 11 & 9 \\
\hline 2003 & 2 & 5 & 12 & 11 & 2 & 7 & 28 & 7 & 8 & 9 \\
\hline 2004 & 1 & 3 & 9 & 11 & 4 & 7 & 27 & 6 & 7 & 9 \\
\hline 2005 & 1 & 5 & 12 & 9 & 3 & 8 & 15 & 6 & 8 & 8 \\
\hline 2006 & 1 & 4 & 15 & 12 & 4 & 9 & 19 & 8 & 7 & 9 \\
\hline 2007 & 2 & 6 & 14 & 12 & 5 & 6 & 16 & 5 & 5 & 8 \\
\hline 2008 & 3 & 2 & 14 & 10 & 4 & 5 & 23 & 5 & 7 & 9 \\
\hline 2009 & 1 & 3 & 10 & 10 & 3 & 10 & 21 & 9 & 8 & 11 \\
\hline 2010 & 2 & 8 & 11 & 7 & 4 & 4 & 21 & 5 & 7 & 9 \\
\hline
\end{tabular}

Source: DCLG (2011) 
Table 3: Overview of the key operational issues and relevant research and educational challenges

\begin{tabular}{|c|c|}
\hline Operational issues & Research and educational challenges in relation to flood risk \\
\hline 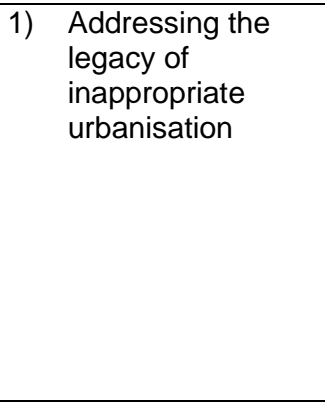 & $\begin{array}{l}\text { - Develop relevant urban multi-hazard/threat risk assessment methodologies } \\
\text { - Develop (and understand the cost/benefits of) innovative new technologies/materials and/or } \\
\text { improve the existing technologies/materials for reducing flood risks and enhancing flood } \\
\text { protection and retrofitting } \\
\text { Better understand how existing properties (particularly those built since the building codes } \\
\text { were changed in 1971) can be made more resilient/resistant to flood risk } \\
\text { - Learn lessons from how other countries (i.e. Scotland and Netherlands) cope with and indeed } \\
\text { live with flood risk and ensure these lessons are used to in the planning and design of new } \\
\text { and existing urban developments } \\
\text { - Assess the most effective (from functional and cost perspectives) ways to resiliently reinstate } \\
\text { flood affected properties }\end{array}$ \\
\hline $\begin{array}{l}\text { 2) Attending to the } \\
\text { impacts of climate } \\
\text { change }\end{array}$ & $\begin{array}{l}\text { - Make accurate climate change data and scenarios available to a broader range of professions } \\
\text { - } \quad \text { i.e. architects, civil engineers, urban planners) } \\
\text { methor understand the impacts of climate change (and specifically flood risk) on modern } \\
\text { - } \quad \text { Compile progressive interactive data banks on a range of natural hazards so that flood risks } \\
\text { can be understood/mitigated in the context of other hazards } \\
\text { - More strongly understand the conceptual and operational links between the resilience and } \\
\text { sustainability agendas, what are the clashes and synergies? } \\
\text { Establish an open access database of good practices for DRR in different contexts (i.e. } \\
\text { different hazards/threats, urban contexts, pre-/post-disaster, types of construction } \\
\text { professionals). }\end{array}$ \\
\hline $\begin{array}{l}\text { 3) Legislation only } \\
\text { goes part of the } \\
\text { way }\end{array}$ & $\begin{array}{l}\text { - Develop (and if possible adopt relevant existing) multidisciplinary frameworks for the } \\
\text { application of mainstreamed DRR into the process of planning and design, implementing and } \\
\text { construction, management and maintenance of the built environment in both pre-disaster and } \\
\text { post disaster situations. } \\
\text { - Learn lessons from how neighbouring nations (i.e. Scotland and Netherlands) cope with and } \\
\text { indeed live with flood risk and ensure these lessons are used to in the planning and design of } \\
\text { new and existing urban developments } \\
\text { Put more power in the hands of local communities, possibly by strengthening the advocacy } \\
\text { roles that organisations such as FLAGS can make in influencing the planning process and } \\
\text { reducing 'flood-blind' developments }\end{array}$ \\
\hline $\begin{array}{l}\text { Increasing the } \\
\text { awareness of who } \\
\text { should do what }\end{array}$ & $\begin{array}{l}\text { - Educate the broad range of disciplines responsible for the delivery and operation of the built } \\
\text { environment so that they know about the notion of DRR in relation to their specific areas of } \\
\text { specialism. This can be achieved through Continued Professional Development (CPD) type } \\
\text { courses but also, ideally, incorporated into the professional training (i.e. } \\
\text { undergraduate/apprentice) of engineers, architects and planners. } \\
\text { Produce bespoke guidance briefs for specific disciplines highlighting their roles in } \\
\text { reducing/eliminating flood risk development/re-development }\end{array}$ \\
\hline $\begin{array}{l}\text { Improving when } \\
\text { key decisions } \\
\text { should be made }\end{array}$ & $\begin{array}{l}\text { - Educate the broad range of disciplines responsible for the delivery and operation of the built } \\
\text { environment so that they know about the notion of DRR in relation to their specific areas of } \\
\text { specialism. } \\
\text { Eliminate/reduce planning loopholes by strengthening the planning system in England so that } \\
\text { it falls more in line with the (more flood risk averse) planning system in Scotland } \\
\text { - Produce bespoke guidance briefs for specific disciplines highlighting their roles in } \\
\text { reducing/eliminating flood risk development/re-development } \\
\text { - Provide training to SMEs in the construction sector on how to resiliently reinstate flood } \\
\text { affected properties }\end{array}$ \\
\hline $\begin{array}{l}\text { Understanding } \\
\text { who pays and the } \\
\text { 'business case' }\end{array}$ & $\begin{array}{l}\text { - Better understand the costs and benefits of DRR (and specifically flood risk reduction) } \\
\text { approaches with the aim of supporting an evidence-based 'business case' for DRR. } \\
\text { - Understand how commercial demand can be generated for new 'resilient' technologies so that } \\
\text { they can become affordable to the private sector/public sector organisations (including SMEs). } \\
\text { - Understand the implications of the new 'Memorandum of Understanding' on the affordability of } \\
\text { flood insurance and the extent to which home owners are prepared to invest in flood reduction } \\
\text { measures } \\
\text { Better understand the most cost-effective ways to resiliently reinstate flood affected properties } \\
\text { and encourage the insurance sector to adopt the best approaches. }\end{array}$ \\
\hline
\end{tabular}


Appendix A: Stakeholder identification and DRR inputs (England): Who should be involved and when should the inputs be made

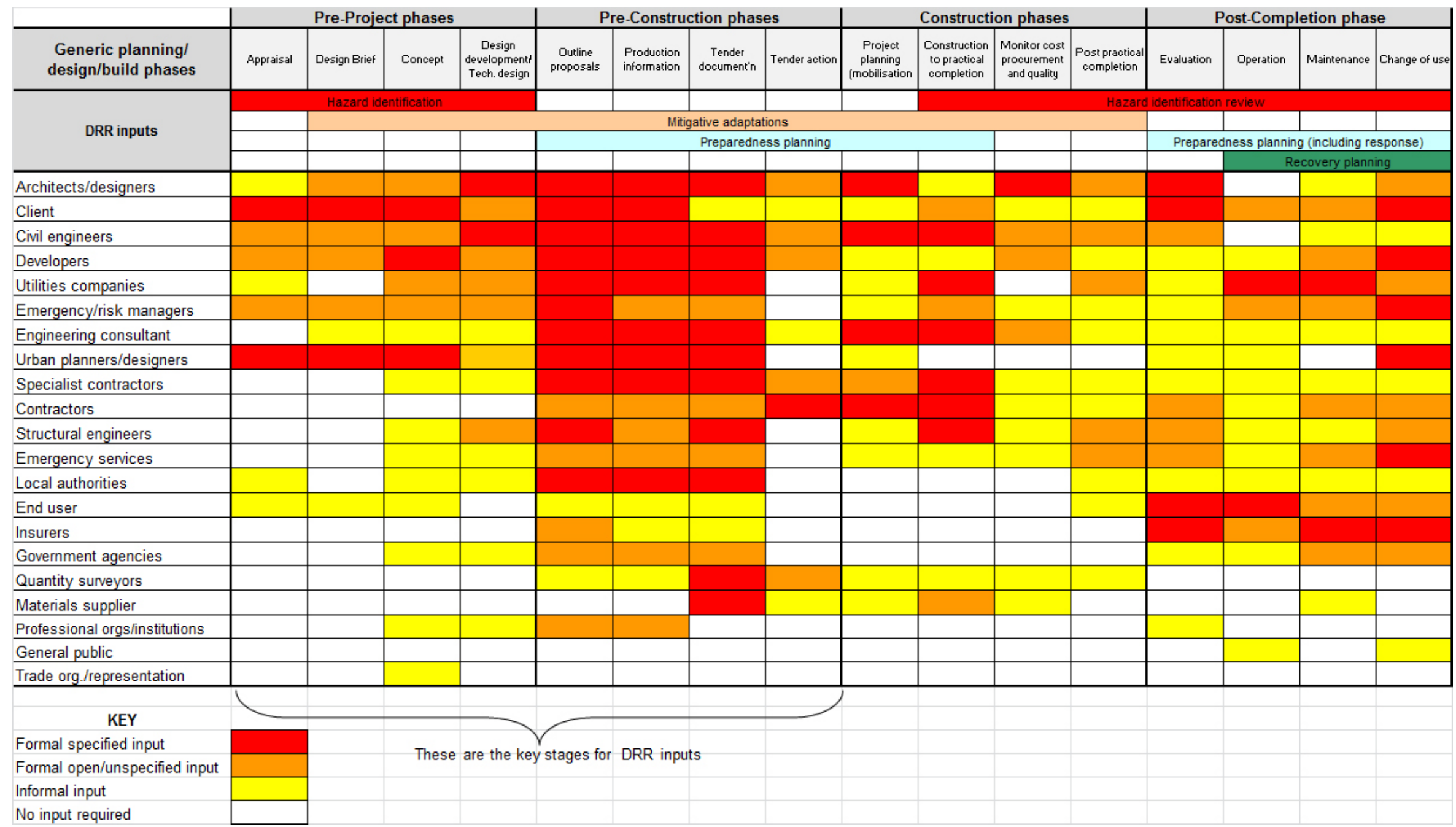


Appendix B: Stakeholder identification and DRR inputs (England): Who is typically involved and when are their inputs usually made

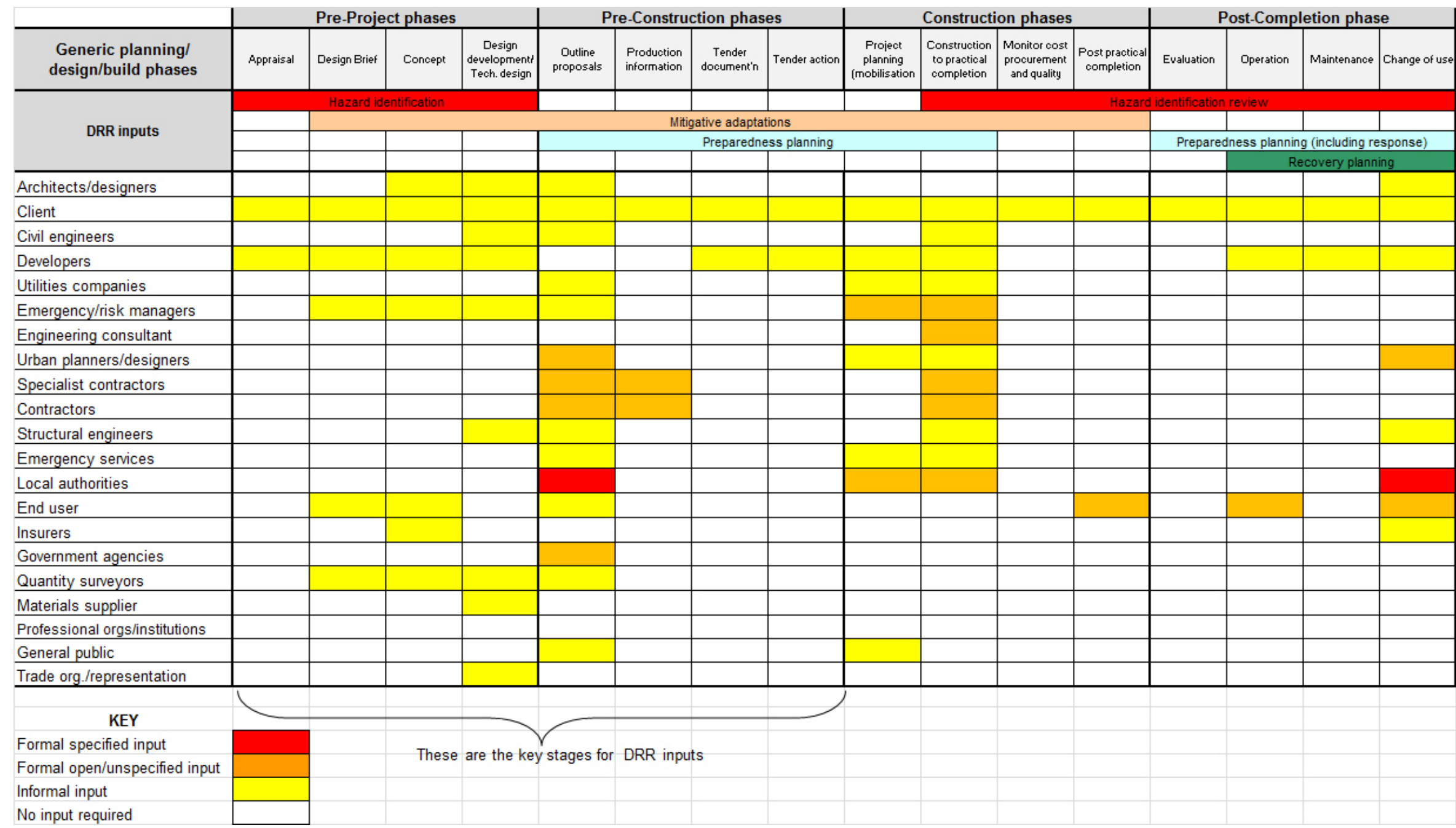




\section{Endnotes}

${ }^{1}$ Of the 30 construction professionals that were approached to take part in the research 16 agreed to be interviewed (six of them also took part in the workshops). These construction professionals, as with the other respondents, were approached due to their previous or on-going involvement in specific types of construction projects in England where natural hazards and manmade threats were prevalent and thus where DRR inputs could/should have been considered. The construction respondents consisted of four directors, three senior engineering consultants, two facilities/asset managers, three architects, two construction managers and two urban/landscape designers.

2 Please refer to Alexander (2013) for a detailed etymological review of 'resilience'.

${ }^{3}$ For instance, recent flooding events in England have also highlighted that placing too much emphasis on the technical and structural approaches to DRR can provide circumstances where the solutions to old problems can end up generating new problems. To illustrate this point, after floods in 2007 the residents of the village of Kempsey in England spent years lobbying for new flood defences that were eventually approved and completed in July 2012 at a cost of $£ 1.5 \mathrm{~m}$. Unfortunately, the defences failed in November and subsequently contributed towards making the impacts of the flood as extensive as previous years (BBC 2012).

${ }^{4}$ This comment refers to the infamous and much pilloried, statement by Defense Secretary Donald Rumsfeld, in 2002 during a United States Government Defense Department briefing, "We know there are known knowns: there are things we know we know. We also know there are known unknowns: that is to say we know there are things we know we don't know. But there are also unknown unknowns - the ones we don't know we don't know".

${ }^{5}$ For instance, Pakistan was severely affected by an earthquake in October 2005 because many modern buildings (including, as some figures have suggested, 17,000 government built schools that collapsed killing an estimated 19,000 children) were not built with sufficient aseismic measures so that they could withstand the effects of earthquakes (the threat of which had been known about for many years) (EERI 2006) ${ }^{6} \mathrm{~A}$ 'Dwelling' in the context of this data is defined as a 'self-contained unit of residential accommodation'.

${ }^{7}$ The figures in Table 1 are for dwellings in 'floodplains' with a 1 in 100 year return period and 'coastal areas' with a 1 in 200 year return period.

${ }^{8}$ Green (2011)

${ }^{9}$ Ramseh (2012)

${ }^{10}$ The Environment Agency (EA 2011) claim that approximately 98 per cent of planning decisions in flood risk areas in England were either amended in line with the EA's advice to address flood risk or withdrawn. However, the report lacks sufficient details explaining what proportions of the objections by the EA were eventually accepted with minor or no modifications or through the addition of flood defences.

${ }^{11}$ Building upon relevant research being conducting at the Universities of Dundee, Aberdeen, Middlesex and Manchester as well as publications by the Construction Industry Research and Information Association (CIRIA) 